\title{
The effect of economic recession on population health
}

\author{
Stephen Bezruchka MD MPH
}

Previously published at www.cmaj.ca on Aug. 31, 2009.

$\mathrm{E}$ conomic recessions have paradoxical effects on the mortality trends of populations in rich countries. Contrary to what might have been expected, economic downturns during the 20th century were associated with declines in mortality rates. In terms of business cycles, mortality is procyclical, meaning it goes up with economic expansions and down with contractions, and not countercyclical (the opposite), as expected. So while most nations enjoyed sustained declines in mortality during the last century, the pace of the decline has been slower during economic booms and greater during so-called busts. The first rigorous studies demonstrating this trend have appeared only in the past 9 years, although the concept is not new. In contrast, for poor countries, shared economic growth appears to improve health by providing the means to meet essential needs such as food, clean water and shelter, as well access to basic health care services. But after a country reaches $\$ 5000$ to $\$ 10000$ gross national product (GNP) per capita (or gross domestic product or gross national income per capita, all of which are similar for our purposes here), few health benefits arise from further economic growth ${ }^{1}$ (Figure 1). Health trends in Sweden illustrate this effect. ${ }^{2}$

\section{Population health and the economy}

The potential health benefits of economic progress can be affected by 2 major influences. ${ }^{3}$ The first is how the income generated by economic growth is used, particularly whether it is used to expand public services appropriately and to reduce the burden of poverty. The second is whether, without economic growth, the available economic resources can be used in a socially productive way. Japan presents a modern example of economic growth that was shared to reduce poverty, achieving what are today the best health outcomes in the world. ${ }^{4} \mathrm{Cuba}$, on the other hand, has not seen much economic advance, yet has achieved remarkable levels of health by using its limited resources to benefit its people. The equitable nature of health status in Cuba is reflected in, for example, the remarkably small health disparities that divide Afro-Cubans and whites in that country. ${ }^{5}$

It should not be surprising that economic growth does not lead to improved health. A wide range of research studies of rich countries have revealed that greater national wealth, by nearly any measure, does not lead to better human welfare. ${ }^{1}$ The United States, with the highest GNP per capita in the world, has a lower life expectancy than nearly all the other rich countries and a few poor ones, despite spending half of the

\section{Key points}

- In rich countries, mortality declines faster during recessions than during periods of economic growth.

- Countries with strong social safety nets see smaller changes in the health of the population related to business cycles.

- The current economic crisis offers an opportunity for rich countries to rethink the social purposes of their economies.

world's health care bill. ${ }^{6}$ The United States also has the greatest levels of poverty of any rich country, with correspondingly poor health outcomes and huge health disparities. ${ }^{1}$ Its population's health is on a par with that of Cuba, a poor nation that has faced economic embargoes for the past 50 years. ${ }^{7}$ The population of the United States is also less healthy than the population of Greece, whose economic status lies in between.

What leads to health in the industrialized countries is not absolute wealth or growth but how the nation's resources are shared across the population. ${ }^{1}$ Above a certain threshold of inequality a more egalitarian income distribution within a rich country is associated with better health. As income inequality has soared in recent years in the United States, relative health improvements have dwindled and greater health disparities have emerged. ${ }^{8}$ In Canada, the association between income inequality and worse health, although present, is not as strong because of better social safety nets compared with the United States, where relatively few government benefits accrue to the less well off.9

\section{The procyclical nature of mortality}

Beginning in the 1920s, analyses of Great Britain and the United States suggested that economic expansions were not good for health. ${ }^{10}$ Because of the nonintuitive nature of these findings, these studies were not taken seriously. Much later, Ruhm ${ }^{11}$ looked at mortality fluctuations with the economy among the 50 US states, from 1972 to 1991, for 3 age groups (20-44 years, 45-64 years, and 65 years and older), together with infant and neonatal mortality. Unemployment rates had a strong inverse relation with all of the mortality measures listed above. For example, a $1 \%$ rise in a state's unemploy-

Stephen Bezruchka is with the Departments of Health Services and Global Health, School of Public Health, University of Washington, Seattle, USA.

Cite as CMAJ 2009. DOI:10.1503/cmaj.090553 
ment rate, relative to its historical average, was associated with a $0.5 \%$ to $0.6 \%$ decrease in total mortality. The effect was particularly strong for young adults in relation to preventable causes of death, including motor vehicle crashes, cardiovascular and liver disease, and influenza and pneumonia. The finding was thought to be related to personal behaviours such as diet, smoking, alcohol use and exercise. Ruhm found the same effect among people in the 65 and older group. The findings were not consistent for all causes of mortality, however; deaths from cancer, for example, did not display this relationship. Suicide has been found to be cyclical, meaning that rates go up during economic downturns; mental health also suffers during such periods. ${ }^{12,13}$ Although homicides do not follow a consistent pattern, ${ }^{14}$ age-adjusted deaths from all causes follow a consistent procyclical pattern.

Further studies have substantiated these ecological findings. In a 2005 study of mortality variations in the United States from 1900 to 1996, Tapia Granados found relative increases during economic expansions..$^{10}$ The economic measures used were changes in GDP, unemployment rate and average weekly hours in manufacturing. The effects tended to be stronger for men over the entire period and for nonwhites during the second half of the century. Sex-related differences became less pronounced for the last 25 years of the period, 1971 to 1996, when women entered the nondomestic workforce in increasing numbers. Studies of other countries, including Japan, Spain and Germany, have yielded similar findings. ${ }^{15-18}$

An important study looked at the health impacts of the Great Depression in 114 US cities for which good data were available. ${ }^{19}$ Infant mortality rates in those cities declined during the period 1929 to 1940, and greater declines were related to increased relief spending associated with the New Deal (a series of economic measures to counter the effects of the Depression through massive public works programs). The reduction in mortality beyond infancy was not as great. Many infectious causes of death were affected by these relief programs, because of better nutrition, sanitation, access to housing and health care, but this benefit was not seen with degenerative or chronic diseases. An oral history of this period in Australia also portrayed substantial social cohesion, even though it was a society under stress. ${ }^{20}$

Laporte $^{21}$ evaluated earlier studies by Brenner, who used complex methods to study macroeconomic indicators and health. Those studies indicated that mortality was countercyclical with the business cycle, but the research has not survived critical scrutiny. The results were found to be sensitive to the choice of indicators, the methods of analysis and the time periods examined..$^{21}$

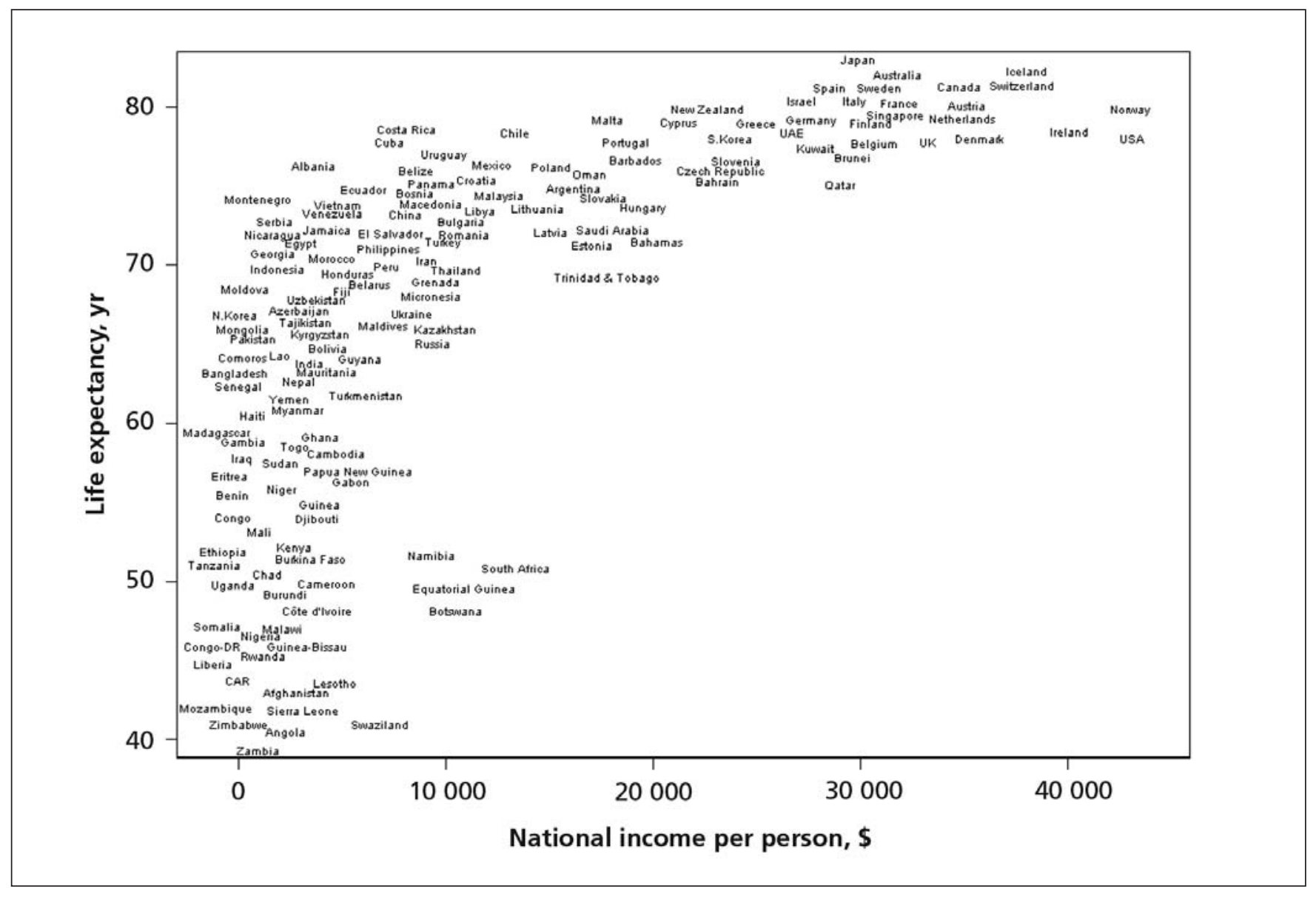

Figure 1: Lack of relationship between life expectancy and gross national product (GNP) per capita among rich countries once they have reached GNP per capita of $\$ 5000$ to $\$ 10000$. Reprinted from Wilkinson and Pickett. ${ }^{1}$ 


\section{Individual studies of unemployment and health}

Studies on the impact of temporary unemployment have demonstrated that being out of work is bad for an individual's health. ${ }^{12,22,23}$ Those analyses did not control for the economic cycle, however. In a recent study, Strully ${ }^{24}$ looked at US interview data pooled from the 1999, 2001 and 2003 Panel Study of Income Dynamics. Respondents were asked about certain aspects of their employment, their self-assessed health and a variety of health conditions. Losing one's job was associated with a 54\% chance of reporting fair or poor health, and for a person with no pre-existing health conditions, the chances of reporting a new one increased by $83 \%$ with job loss. Job "churning," a situation in which rates of job loss are high but there is low unemployment, was also associated with the reporting of more poor health conditions.

Dehejia and Lleras-Muney found that employment rates at the time of conception were correlated with better early life outcomes in the United States during periods of high unemployment. ${ }^{25}$ Rates of low birth weight and of postneonatal mortality are better for children conceived during periods of high unemployment, perhaps because women have more time to deal with the stress of pregnancy and to devote to infant care. This observation is consistent with research demonstrating that a large fraction of our health as adults is determined in early life. ${ }^{26}$

\section{Recessions and social safety nets}

To better understand how recessions paradoxically improve the health of populations requires an examination of the determinants of health, including how societies share resources among their members. An important study considered the economy and health among nations of the Organisation for Economic Co-operation and Development (OECD). ${ }^{27}$ These countries have a wide range of social insurance systems, from limited social support, as in the United States, to strong safety nets, as in the Scandinavian nations. The research considered how total mortality and 9 causes of death varied with national unemployment rates in the 23 member nations over the period from 1960 to 1997 . The authors found that mortality increased during the so-called good times or economic booms, with contrasting trends during downturns (Figure 2). The effects were more modest in countries with strong labour protection and high levels of spending on social insurance and more pronounced in countries without such protections. Three groups of nations were identified. The first comprised Germany, the Netherlands, Austria, Norway, France, Finland, Denmark and Sweden, which devoted an average of $28.7 \%$ of GDP to public social programs and with had the least (beneficial) impact of recession on health (that is, fewer mortality benefits during recessions). The intermediate group, consisting of Spain, New Zealand, Luxembourg, Poland, Italy, the United Kingdom, Switzerland and Belgium, spent $23.5 \%$ of GDP on social welfare and had intermediate health outcomes during recessions. The most procyclical outcomes were observed in the third group (Japan, the United States, Portugal, Australia, the Czech Republic, Ireland and Canada), which spent $18.9 \%$ on social support programs.

The causes of death most affected in that study were heart disease, influenza and pneumonia, liver disease, motor vehicle crashes and other unintentional incidents (including those related to the workplace) and infant mortality. The strength of the effects were somewhat weaker than those reported by Ruhm ${ }^{11}$ in his pioneering study and were thought

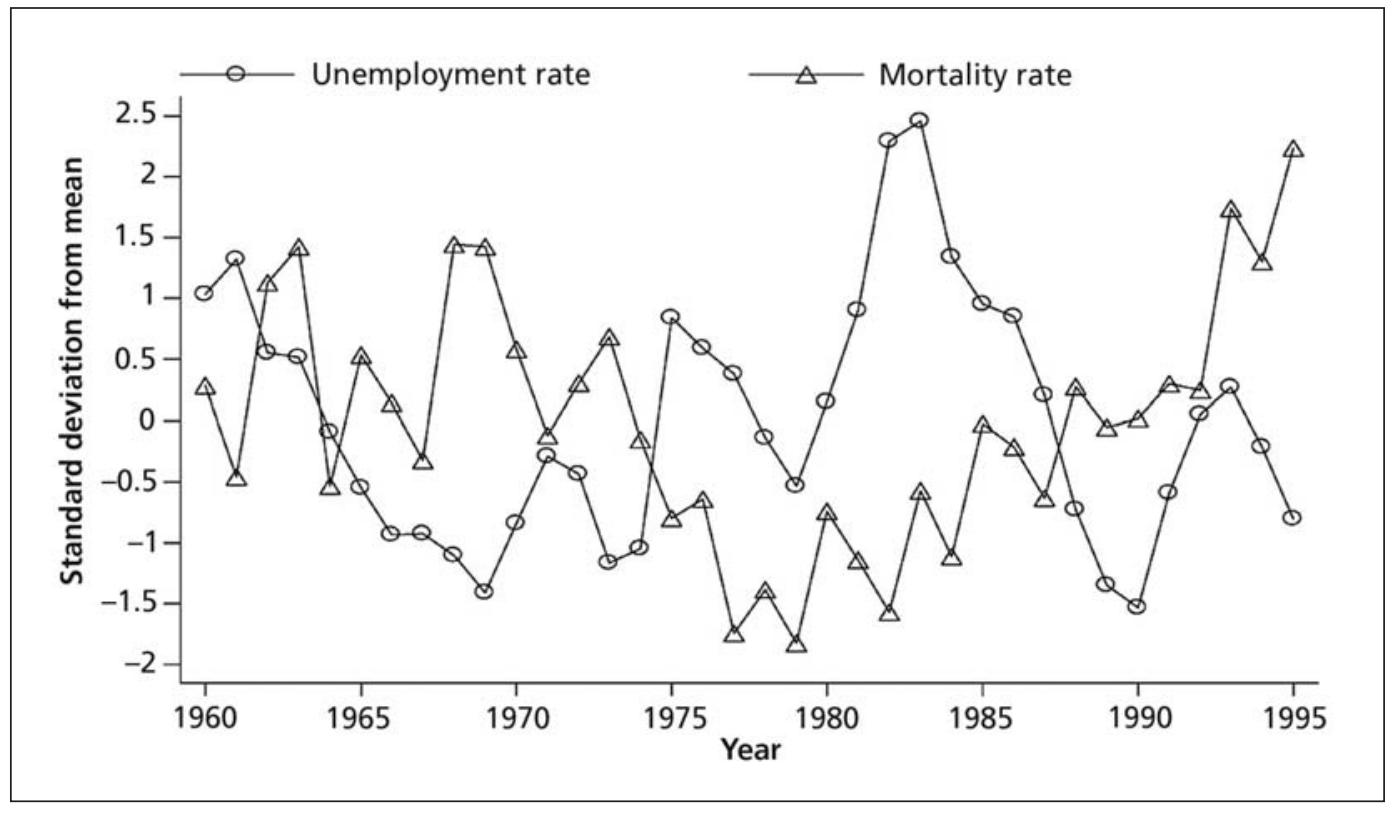

Figure 2: Mortality rates and unemployment rates in countries in the Organisation for Economic Co-operation and Development for the period 1960 to 1995, expressed as standard deviation from the mean. ${ }^{25}$ Reprinted with permission from Elsevier. 
to be related to national differences such as shorter working hours and more stringent job safety regulations in European countries than in the United States. The authors of the OECD study $^{27}$ pointed out that the results could be applied only to transient labour market changes and not to permanent ones. The results of a recent study ${ }^{28}$ are consistent with these findings. In Sweden, studies using individual-level and panel data have revealed countercyclical mortality at least for workingage men and for deaths from myocardial infarction..$^{29,30}$ Sweden has strong social and economic supports that may buffer the health impacts of economic cycles. Individual-level studies in the United States have suggested that working-age men with more education suffer more adverse health impacts from economic booms. ${ }^{31}$ One major concern in the United States during the current recession is that rising unemployment is leading to the loss of health care insurance for many. However, health care has not been found to be a major factor in producing health in populations, although access to highquality health care is still an important social good. ${ }^{32}$

\section{Mechanisms through which recessions can improve the health of societies}

There are myriad mechanisms through which health can improve during economic downturns. Increased leisure time can be used for friendships, exercise and enjoyable physical activity and can be spent with family. ${ }^{33-37}$ Having friends is known to be good for health. ${ }^{38}$ Having time to spend with children may yield even greater benefits for future generations. Some studies have suggested that adverse health behaviours such as smoking and excessive alcohol use decline during recessions. Overeating also declines. ${ }^{35}$ Conversely, when employment is associated with stress in the workplace and low control on the job, the worker's health is likely to suffer. ${ }^{39}$ These effects of stress have also been observed for fetuses in utero and therefore affect a woman's progeny..$^{40}$ Stress and inflammation are the organ and cellular mechanisms through which these factors may operate, and early life is the key period during which such effects are likely strongest. ${ }^{41}$

The poor health situation in the United States can be related to the lack of wage growth in that country over the past 40 years, a trend that has required many citizens to work very long hours, often at several jobs, to ensure an adequate income. Female life expectancy has declined in a fifth of US counties in recent years, in contrast to trends during earlier periods, when there was less inequality. ${ }^{8}$ Studies of the relation between income inequality and adverse health suggest that relative deprivation matters more than absolute deprivation. ${ }^{1,42,43}$ The judgments that people make about where they stand in comparison to others in the social hierarchy may become more self-critical during periods of economic growth, which could adversely affect health.

Recent analysis ${ }^{44}$ has confirmed Ruhm' ${ }^{11}$ original findings of strong procyclical mortality trends for the United States, suggesting that personal health-related behaviors may not be the primary mechanisms. The largest reduction in deaths occur among older people, from causes that include motor vehicle crashes, as well as cardiovascular and respiratory diseases, infections, degenerative brain conditions and homicide. Miller and colleagues ${ }^{44}$ have suggested that the root causes are economic externalities, a view consistent with the primordial determinants of population health presented here.

\section{Today's recession represents an opportunity}

Health gradients exist in every society, those lower down the socioeconomic ladder having worse health than those above. ${ }^{39}$ Poorer people will always do worse in any given economic situation, whether it be boom or bust and whether they are employed or not. But, as was clearly seen in the OECD countries, ${ }^{27}$ in nations with greater social safety nets, the health impacts of economic cycles are less pronounced. There is also evidence that when the unemployment rate rises during a recession, the health benefits of being employed are lower. ${ }^{45}$ Given these findings, there are many policies that could be implemented to benefit whole societies, protecting them from the health effects of business cycles.

Strengthening the support provided by social safety nets - whether related to health care, employment security, housing, food or early life support - would help to buffer the effects of shifts in the economy and would promote health rather than threaten it. Attention could also be directed toward scaling back rich economies and devoting efforts to those nations currently below $\$ 5000$ GDP per capita. The latter nations would see profound improvements in health, while those of us in richer nations might also see some health benefits, in addition to realizing a more sustainable future. It could be a win-win situation, with the planet as a whole suffering less environmental stress. ${ }^{1}$

Today's recession could also represent a global stimulus to redirect societal goals through wealth redistribution, in the same way the Great Depression did almost 80 years ago. Global health disparities are at unparalleled extremes, and we would all benefit from decreasing economic inequalities, not least through lessening the health gap. ${ }^{1}$ Debate and discussion about these possibilities, viewed from different political perspectives, is already underway around the globe.

Nobel laureate Amartya Sen has presented examples of the approaches that different nations have taken to better health. In particular, he contrasted jurisdictions with shared economic growth strategies (South Korea and Taiwan) with those that have achieved good health without high economic growth but through support-led processes (Sri Lanka, pre-reform China and the Indian state of Kerala). He also presented Britain as a historical example of the latter approach, it being a country that enjoyed its greatest health improvements over the 20th century during periods of lowest economic growth.

A first step in applying our understanding of the health trends of the last century would be to make known the health effects of various economic choices. If we recognize that economic growth may not good for our health, then we can consider means of reining in the excess wealth (which has been justified by its production of growth) and of redistributing national resources through social spending for the common good. Creating such awareness through knowledge translation 
would be a critical approach that health care providers and administrators can undertake as they advocate for health in addition to treating illness. ${ }^{46,47}$

This article has been peer reviewed.

Competing interests: None declared.

\section{REFERENCES}

1. Wilkinson R, Pickett KE. The spirit level: why more equal societies almost always do better. London (UK): Penguin; 2009.

2. Tapia Granados JA, Ionides EL. The reversal of the relation between economic growth and health progress: Sweden in the 19th and 20th centuries. J Health Econ 2008;27:544-63.

3. Sen A. Economic progress and health. In: Leon DA, Walt G, editors. Poverty, inequality and health: an international perspective. Oxford University Press (UK): Oxford; 2001. p. 333-45.

4. Bezruchka S, Namekata T, Sistrom MG. Improving economic equality and health: the case of postwar Japan. Am J Public Health 2008;98:589-94.

5. de la Fuente A. Race and inequality in Cuba, 1899-1981. J Contemp Hist 1995;30:131-68.

6. Bezruchka S. Epidemiological approaches. In: Raphael D, Bryant T, Rioux M, editors. Staying alive: critical perspectives on health, illness and health care. Toronto (ON): Canadian Scholars' Press; 2006. p. 13-33.

7. Spiegel JM. Commentary: Daring to learn from a good example and break the "Cuba taboo." Int J Epidemiol 2006;35:825-6.

8. Ezzati M, Friedman AB, Kulkarni SC, et al. The reversal of fortunes: trends in county mortality and cross-county mortality disparities in the United States. PLoS Med 2008;5:e66.

9. Siddiqi A, Hertzman C. Towards an epidemiological understanding of the effects of long-term institutional changes on population health: a case study of Canada versus the USA. Soc Sci Med 2007;64:589-603.

10. Tapia Granados JA. Increasing mortality during the expansions of the US economy, 1900-1996. Int J Epidemiol 2005;34:1194-202.

11. Ruhm CJ. Are recessions good for your health? Q J Econ 2000;115:617-50.

12. Jin RL, Shah CP, Svoboda TJ. The impact of unemployment on health - a review of the evidence. CMAJ 1995;153:529-40.

13. Solantaus T, Leinonen J, Punamaki RL. Children's mental health in times of economic recession: replication and extension of the family economic stress model in Finland. Dev Psychol 2004;40:412-29.

14. Ruhm CJ. Macroeconomic conditions, health and mortality. In: Jones AM, editor. The Elgar companion to health economics. Cheltenham (UK): Edward Elgar Publishing; 2006. p. 5-16.

15. Kondo N, Subramanian SV, Kawachi I, et al. Economic recession and health inequalities in Japan: analysis with a national sample, 1986-2001. J Epidemiol Community Health 2008;62:869-75.

16. Neumayer E. Recessions lower (some) mortality rates: evidence from Germany. Soc Sci Med 2004;58:1037-47.

17. Tapia Granados JA. Recessions and mortality in Spain, 1980-1997. Eur J Popul 2005;21:393-422.

18. Tapia Granados JA. Macroeconomic fluctuations and mortality in postwar Japan. Demography 2008;45:323-43.

19. Fishback PV, Haines MR, Kantor S. Births, deaths, and New Deal relief during the Great Depression. Rev Econ Stat 2007;89:1-14.

20. Potts DJ. The myth of the Great Depression. Melbourne (Australia): Scribe; 2006.

21. Laporte A. Do economic cycles have a permanent effect on population health? Revisiting the Brenner hypothesis. Health Econ 2004;13:767-79.
22. Dorling D. Unemployment and health. BMJ 2009;338:1091-2.

23. Bambra C, Eikemo TA. Welfare state regimes, unemployment and health: a comparative study of the relationship between unemployment and self-reported health in 23 European countries. J Epidemiol Community Health 2009;63:92-8.

24. Strully KW. Job loss and health in the US labor market. Demography 2009;46:221-46.

25. Dehejia R, Lleras-Muney A. Booms, busts, and babies' health. Q J Econ 2004;119: 1091-130

26. Hertzman C, Power C. A life course approach to health and human development. In: Heymann J, Hertzman C, Barer ML, et al., editors. Healthier societies: from analysis to action. New York (NY): Oxford University Press; 2006. p. 83-106.

27. Gerdtham UG, Ruhm CJ. Deaths rise in good economic times: evidence from the OECD. Econ Hum Biol 2006;4:298-316.

28. Stuckler D, Basu S, Suhrcke M, et al. The public health effect of economic crises and alternative policy responses in Europe: an empirical analysis. Lancet 2009;374:315-23.

29. Gerdtham UG, Johannesson M. Business cycles and mortality: results from Swedish microdata. Soc Sci Med 2005;60:205-18.

30. Svensson M. Do not go breaking your heart: Do economic upturns really increase heart attack mortality? Soc Sci Med 2007;65:833-41.

31. Edwards R. Who is hurt by procyclical mortality? Soc Sci Med 2008;67:2051-8.

32. Roos NP, Brownell M, Menec V. Universal medical care and health inequalities: right objectives, insufficient tools. In: Heymann J, Hertzman C, Barer ML, et al., editors. Healthier societies: from analysis to action. New York (NY): Oxford University Press; 2006. p. 107-31.

33. Ruhm CJ. Good times make you sick. J Health Econ 2003;22:637-58

34. Ruhm CJ. Commentary: mortality increases during economic upturns. Int J Epidemiol 2005;34:1206-11.

35. Ruhm CJ. Healthy living in hard times. J Health Econ 2005;24:341-63.

36. Ruhm CJ. A healthy economy can break your heart. Demography 2007;44:829-48.

37. Ruhm CJ, Black WE. Does drinking really decrease in bad times? J Health Econ 2002;21:659-78

38. Berkman L, Glass T. Social integration, social networks, social support, and health In: Berkman LF, Kawachi I, editors. Social epidemiology. New York (NY): Oxford University Press; 2000. p. 137-73.

39. Marmot M. Status syndrome - how our position on the social gradient affects longevity and health. London (UK): Bloomsbury; 2004

40. Gluckman PD, Hanson MA, Cooper C, et al. Effect of in utero and early-life conditions on adult health and disease. $N$ Engl J Med 2008;359:61-73.

41. Entringer S, Kumsta R, Nelson EL, et al. Influence of prenatal psychosocial stress on cytokine production in adult women. Dev Psychobiol 2008;50:579-87.

42. Eibner C, Evans WN. The income-health relationship and the role of relative deprivation. In: Neckerman KM, editor. Social inequality. New York (NY): Russell Sage Foundation; 2004. p. 545-68.

43. Eibner C, Evans WN. Relative deprivation, poor health habits, and mortality. $J$ Hum Resour 2005;40:591-620.

44. Miller DL, ME Page, Stevens AH, Mateusz F. Why are recessions good for you health? Am Econ Rev 2009;99:122-7.

45. Martikainen PT, Valkonen T. Excess mortality of unemployed men and women during a period of rapidly increasing unemployment. Lancet 1996;348:909-12.

46. Bezruchka S. Becoming a public scholar to improve the health of the US population. Antipode 2008;40:455-62.

47. Bezruchka S. Promoting public understanding of population health. In: Babones SJ, editor. Social inequality and public health. Bristol (UK): Policy Press; 2009. p 201-14

Correspondence to: Dr. Stephen Bezruchka, Departments of Health Services and Global Health, School of Public Health, Box 357660, University of Washington, Seattle WA 98195-7660, USA; fax 206 685-4181; sabez@u.washington.edu

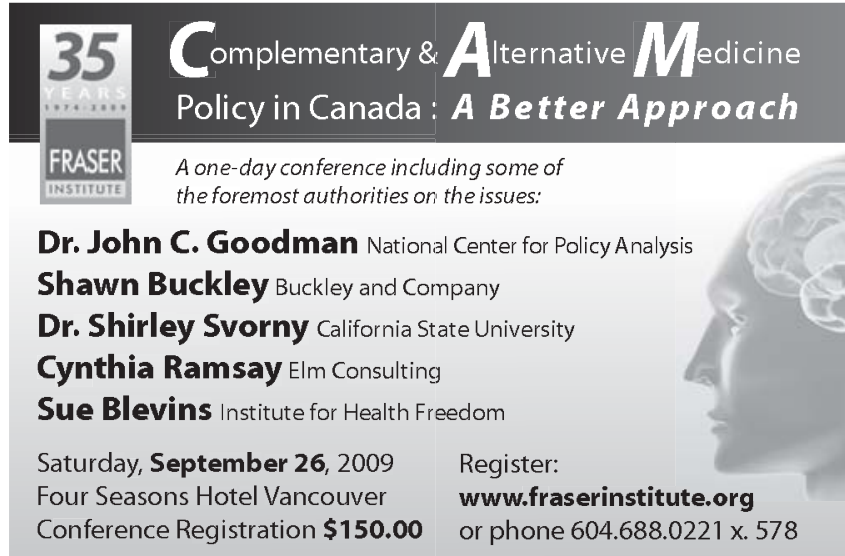

